\title{
Ethno-nationalism and impediments to cooperation in tourism in a post-settlement Cyprus?
}

\author{
Craig Webster, David Jacobson and Kelsey Shapiro
}

\author{
Craig Webster is an Assistant \\ Professor at the Department of \\ Family and Consumer \\ Sciences, Ball State University, \\ Muncie, Indiana, USA. \\ David Jacobson is an Emeritus \\ Professor of Economics at the \\ Department of Economics, \\ DCU Business School, \\ Dublin, Ireland. \\ Kelsey Shapiro is based at the \\ Ball State University, Muncie, \\ Indiana, USA.
}

\begin{abstract}
Purpose - The purpose of this paper is to clarify the position of Greek Cypriot and Turkish Cypriot professionals in the hotel and tourism industry on the island of Cyprus with regards to their expectations regarding the benefit of a political solution to the Cyprus problem on the island.

Design/methodology/approach - The paper uses data from two surveys in both political entities of the island. One survey is a survey of hotel owners, managers of hotels and travel agencies in both political entities on the island. The other is semi-structured interview with leading professionals in the hospitality and tourism industry in both political entities.

Findings - The surveys indicate that there is an expectation from professionals in both entities that tourism will benefit all following a solution, with large increases in incoming tourism to Cyprus.

Practical implications - The findings indicate that there are substantial expectations that there will be benefits for all following a solution to the Cyprus problem.

Originality/value - This is a first future-oriented paper regarding the expectations of major players in the hotel and tourism industry in both political entities on the island.

Keywords Governance, Politics, Hotels, Futures

Paper type Research paper
\end{abstract}

\section{Introduction}

Cyprus is a politically divided island that consists of two major political entities, the "Turkish Republic of Northern Cyprus" and the Republic of Cyprus. The "Turkish Republic of Northern Cyprus" is recognized only by Turkey and is populated by Turkish Cypriots and settlers from mainland Turkey; the Republic of Cyprus is a member country of the European Union and is populated mainly by Greek Cypriots. The two have been separated by UN-administered "Green Line" since the Turkish invasion of 1974. About a third of the island - in the north - is occupied by Turkey. Here, we discuss how tourism professionals envision the prospects of current and future cooperation between the two prevailing ethnic groups on the island that has a history of bloody interactions and has largely been separated from each other since 1974.

The Republic of Cyprus came into being in 1960. It had been under the Ottomans for centuries until 1878, when the British took over administration with Ottoman approval. The island was annexed outright by the British during First World War. Following a complex armed struggle for unity with Greece and full independence as alternative aims, further complicated by differences between Greek Cypriots and Turkish Cypriots, the British eventually withdrew leaving the island in the control of the newly independent Republic of Cyprus. The British retained direct political 
control over significant British military bases on the island that are still British to this day. The new republic's population consisted primarily of Greek Cypriots (77 percent of the population of the island) and Turkish Cypriots (18 percent of the population), according to the census (Republic of Cyprus, 1961).

After years of turmoil, in 1974 a coup engineered from Athens ousted the President of the Republic (Makarios) for a short time. Ostensibly to protect the Turkish Cypriot minority, Turkey responded with an invasion euphemistically called a "peace operation," capturing about a third of the island's territory. It is this territory that became the "Turkish Republic of Northern Cyprus" while the remaining areas (other than the Green Line and the British bases) are controlled by the Republic of Cyprus. The Republic of Cyprus is still the recognized as the authority presiding over the whole island, although de facto this is not the case.

Even before 1974, Greek Cypriots and Turkish Cypriots have had economies and societies that were very much segregated. Since 1974, the Greek Cypriots and the Turkish Cypriots have lived in radically different political systems and with very different economies. However, since the 1974 invasion, there have been continuous attempts by the UN and Western countries to re-unite the island in one way or another. Although one after another attempts have failed to bring both entities into a confederation, federation, or so other long-term remedy, the attempts to get Turkish Cypriots and Greek Cypriots into one legal country persist. One of the elements of a united island will be the tourism industry, a major player on the economy of the island of Cyprus. Here, we look into the data from a survey of tourism professionals to deal with the political issue of cooperation between Turkish Cypriots and Greek Cypriots, albeit in something that outsiders would not necessarily view as political, tourism.

This is an appropriate time to consider the relationship between the two communities on the island, and the implications for tourism, because a new leader has just been elected (April 2015) in the North. Moreover, this new leader, Mustafa Akinci, has a strong record of cooperation with Greek Cypriots during his term as Mayor of Northern Nicosia (Psillides, 2015). The Greek Cypriot Nicos Anastasiades, who became president in 2013, also stood on an electoral platform of settlement with the North, having publicly supported the UN proposal for resolution of the Cyprus problem, the Annan Plan, in 2014. Meetings between the two leaders in May 2015 have generated optimism. Moreover, "with Greek Cypriots only just emerging from their worst economic crisis in decades and Turkey keen for a foreign policy success, the time is also ripe. Optimism has been further boosted by Athens and Ankara displaying a rare desire to improve ties" (Smith, 2015b).

The paper proceeds as follows. First, we deal with the literature on the division of the island and prospects for the Cypriot economy post-settlement, especially in regards to the notion of the health of the tourism industry. Second, we describe the method by which we could gather insight from tourism professionals about how they considered cooperation with the "others" under current circumstances as well as prospects for cooperation with the "others" following a settlement. We then look into the data that illustrate how tourism professionals envision current and future cooperation. We conclude with some considerations about how Greek Cypriots and Turkish Cypriots and their ethno-political thinking play a role in how the future of tourism in a postsettlement Cyprus may play out.

\section{Literature review}

There is a vast literature linked with tourism and conflict, and recently two major edited works have been produced (Moufakkir and Kelly, 2010; Wohlmuther and Wintersteiner, 2014). There are many other writings that have dealt with the issue of tourism and conflict. Writings focus on specific cases such as Ireland (Anderson and O'Dowd, 1999; Anson, 1999; Boyd, 1999; Leslie, 1999; McDowell, 2008; Zuelow, 2006), the Basque country (Abadie and Gardeazabal, 2003; Plaza, 2002), the Middle East (Brin, 2006; Cohen-Hattab, 2004; Gelbman, 2008; Gelbman and Timothy, 2011; Mansfeld, 1996), or Korea (Seongseop Kim and Prideaux, 2006; Chung and Yu, 2001). But there are other writings that deal with more general/theoretical issues on the topic (Araña and León, 2008; Coshall, 2003; Etxebarria and Gomez Uranga, 2002; Hall and O'Sullivan, 1996; Law, 2006; Neumayer, 2004). Webster and Ivanov (2014) make a contribution in which 
they look into how liberal concepts of economic and social interactions should result in encouragement of economic growth; a virtuous cycle of economic benefit and social encouragement, with economic growth, is created that seems to work in conditions in which the liberal preconditions are met.

Cyprus, too, has been the subject of a significant literature on political division and the implications for tourism. There are many works that deal with tourism development in the "Turkish Republic of Northern Cyprus" (Altinay, 2000; Altinay et al., 2002; Altinay and Hussain, 2005), sometimes speculating about the gains a settlement on the island would bring but more frequently explaining the difficult circumstances that the division of the island creates for the Turkish Cypriot political entity on the island. Greek Cypriot analogues to this are rare (but see loannides and Apostolopoulos, 1999) and this is no surprise as Turkish Cypriot political and economic isolation from the non-Turkish world is quite acute. There is also a small literature that deals with the division of the island and the entire island's potential for tourism (Sönmez and Apostolopoulos, 2000) and the potential for tourism to play a leading role in terms of encouraging a positive cycle of cooperation between Greek Cypriots and Turkish Cypriots (Scott, 2012; Flynn et al., 2012; Hadjipavlou, 2007; Lisle, 2007; Sharpley, 2001; Webster and Timothy, 2006).

While the bulk of the research on tourism in Cyprus either focusses on the current difficulties in cooperation between the two prevailing entities on the island or laments historical developments that have made cooperation and the development of cooperation difficult, in recent years there is a literature that has developed to discuss the future. For example, Webster et al. (2009) looked into how Greek Cypriots involved in the tourism industry perceive cooperation with Turkish Cypriots, looking at how this could inform future cooperation and tourism development, a perspective similar to that of Musyck et al. (2010), Flynn et al. (2012), Jacobson et al. (2010), and Tourism \& Transport Consult International (2004).

Here, we focus mostly on the future and the projections of tourism professionals on both sides of the ethno-political divide in Cyprus, based upon a comprehensive study of tourism professionals on both sides of the divide in Cyprus. We now explain the methodology of the research, including how data were gathered to ascertain prospects for cooperation between Greek Cypriots and Turkish Cypriots in a post-settlement Cyprus.

\section{Methodology}

Asking questions about the future in tourism is now an established strand in the tourism literature. The leader in the field has been Ian Yeoman (Yeoman and Lederer, 2005; Yeoman, 2008, 2012) but many others have been contributing (Dwyer et al. , 2009; Leigh et al. , 2013) and this has culminated - in an academic sense - in a new journal, Journal of Tourism Futures. The approach taken in this paper is more constrained than that of most futurologists of tourism, who tend to focus on megatrends to identify the broad sweep of change. Our approach is to focus more narrowly on the likelihood of future cooperation. Given the long history of conflict, the relative dearth of cooperation between tourism professionals North and South has not been surprising. That there has been any cooperation at all (see Webster et al., 2009 and Table I) is remarkable.

Table I Currently engaged in any cooperation with the other side?

\begin{tabular}{lcccc} 
Response & $\begin{array}{c}\text { Greek Cypriots } \\
\text { Frequency }\end{array}$ & $\begin{array}{c}\text { Greek Cypriots } \\
\%\end{array}$ & $\begin{array}{c}\text { Turkish Cypriots } \\
\text { Frequency }\end{array}$ & $\begin{array}{c}\text { Turkish Cypriots } \\
\%\end{array}$ \\
\hline Yes & 10 & 10.9 & 14 & 20.0 \\
No & 67 & 72.8 & 43 & 61.4 \\
n/a or refusal & 15 & 16.3 & 15 & 21.4 \\
Total & 92 & 100.0 & 70 & 100.0 \\
& & & & \\
Source: Mehmet et al. (2008) & &
\end{tabular}


To learn about the future of a cooperative relationship between Greek Cypriots and Turkish Cypriots, a survey of tourism professionals was carried out. A detailed description of the methods and basic findings from the research can be found in Mehmet et al. (2008).

There were two types of surveys, one of owners or managers of hotels, guest houses and travel agencies, North and South, and the other a Key Informant Survey, really a series of interviews, with specific individuals who were known to have knowledge of the subject. In the North, the total number of respondents to the survey was 70, and in the South, 92.

The survey instrument was a detailed questionnaire on, among other things, the nature of the firm, the number and qualifications of employees, activities - if any - on the "other side," what they expect to happen in relation to settlement of the Cyprus problem in the future, and how such a settlement would affect cooperation and the tourism business in general. It is on the latter items, the perspectives on the future that we focus in this paper. The underlying methodological argument is that what tourism professionals express in a survey about how they would behave in the future, is a reasonable predictor of the future of the tourism industry.

In the Key Informant Survey open interviews were undertaken with ten representatives of the tourist industry in the North, and with four in the South; in addition, the Cyprus Tourism Organization (in the South) provided a statement.

\section{Results and analysis}

\section{Survey of tourism professionals - quantitative}

In order to better understand the context of the future projections, the first table we present here is on the extent to which cooperation has existed at all in recent years in Cyprus. As can be seen from Table I a significant minority (nearly 11 percent in the South and 20 percent in the North) of tourism professionals have been involved in some kind of cooperation with the other side. Two main types of cooperation were described: arranging visits to the other side, and liaising with tour guides and tourist agencies on the other side.

Table II describes the perception of tourism professionals on each side as to how a settlement acceptable to both sides would affect the tourism industry, in comparison to a continuation in the absence of a settlement. The vast majority on both sides see an overall gain, with both sides experiencing an improvement as a result of a settlement. The perceptions are somewhat asymmetrical, with the Turkish Cypriots more optimistic than the Greek Cypriots, both about improved performance in the event that there is, and even if there is not, a settlement acceptable to both sides. The Turkish Cypriots also seem to be more optimistic about improvements in tourism leading to gains for both sides; a significant minority of Greek Cypriots see themselves losing out while Turkish Cypriots gain, both from a settlement (10.9 percent) and from continuation of the status quo (27.2 percent). No Turkish Cypriots at all had such perceptions of loss to themselves while the other side gains.

Table II Impact of status quo vs future settlement

\begin{tabular}{|c|c|c|c|c|}
\hline \multirow[b]{2}{*}{ Likely impact } & \multicolumn{2}{|c|}{ Greek Cypriots } & \multicolumn{2}{|c|}{ rkish } \\
\hline & $\begin{array}{l}\text { Continuation } \\
\text { Frequency (\%) }\end{array}$ & $\begin{array}{l}\text { Settlement } \\
\text { Frequency (\%) }\end{array}$ & $\begin{array}{l}\text { Continuation } \\
\text { Frequency (\%) }\end{array}$ & $\begin{array}{c}\text { Settlement } \\
\text { Frequency (\%) }\end{array}$ \\
\hline Win-win for both side & $11(12 \%)$ & $73(79.3 \%)$ & $52(74.3 \%)$ & $69(98.6 \%)$ \\
\hline Win for GCs and lose for TCs & $7(7.6 \%)$ & $0(0 \%)$ & $18(25.7 \%)$ & $1(1.4 \%)$ \\
\hline Win for TCs and lose for GCs & $25(27.2 \%)$ & $10(10.9 \%)$ & $0(0 \%)$ & $0(0 \%)$ \\
\hline Lose for TCs and lose for GCs & $41(44.6 \%)$ & $3(3.3 \%)$ & $0(0 \%)$ & $0(0 \%)$ \\
\hline$n / a$ & $8(8.7 \%)$ & $6(6.4 \%)$ & $0(0 \%)$ & $0(0 \%)$ \\
\hline Total & $92(100 \%)$ & $92(100 \%)$ & $72(100 \%)$ & $0(0 \%)$ \\
\hline
\end{tabular}

Source: Mehmet et al. (2008) 
There appears to be a paradox in that despite their greater optimism about tourism gains for both sides from a settlement, the Turkish Cypriots are much more pessimistic about the likelihood of a future settlement at all. Table III shows the levels of optimism among Turkish Cypriots are much lower than those of the Greek Cypriots, in relation to whether there will be a settlement acceptable to both sides in the next ten years. If we weight "not at all" as 0 , and "Low" to "Extremely high" from 1 to 4, the weighted average of optimism of the Turkish Cypriot tourism professionals is 0.6, while that for the Greek Cypriots is nearly three times as high, at 1.6.

One explanation for this is that the survey was conducted in the period after the rejection by the Greek Cypriots of the Annan Plan. This was Kofi Annan's proposal for the reunification of Cyprus. In a referendum undertaken on both sides on the same day, April 24, 2004, it was approved by 65 percent of Turkish Cypriots and rejected by 75 percent of Greek Cypriots, with serious consequences for the future of Cyprus (Sachs, 2004; Vural and Peristianis, 2008). Among these, it is likely that there was a diminution in the Turkish Cypriots' expectations of support for a settlement from the Greek Cypriots. The Turkish Cypriot tourism professionals still expect great gains from a settlement, but in response to the Greek Cypriot rejection of the Annan Plan, are pessimistic about the possibility of such a settlement.

Important differences between tourism professionals North and South are evident from Tables I to III. Some of these differences - in particular the pessimism among Turkish Cypriots about the prospects for a settlement - are explained by the Greek Cypriot rejection of the Annan Plan. There are other differences, reflected, for example in Table II, that are probably more closely related to the actual conditions facing the tourist industry in the North and South of the island at the time of the survey. The standard and cost of living were lower in the North than in the South (Noë and Watson, 2005) and hence costs to tourists of accommodation and food were also lower in the North. At the same time the level of development of the infrastructure for the supply of tourist services was also lower in the North. These facts at least in part explain the asymmetry of Table II.

Under 8 percent of Greek Cypriot tourism professionals see a continuation of the status quo leading to Greek Cypriot gain and Turkish Cypriot loss; a much greater 27 percent see it leading to Turkish Cypriot gain and Greek Cypriot loss. Both those in the 8 percent and those in 27 percent could have been correct, depending on their particular sectors of the tourist industry; the former could be supplying tourist services dependent on the more sophisticated infrastructure of the South, the latter supplying the more price sensitive mass market. The equivalent figures for the Turkish Cypriot tourism professionals are very different, nearly 26 percent seeing a continuation of the status quo leading to Greek Cypriot gain and Turkish Cypriot loss with none at all seeing it leading to Turkish Cypriot gain and Greek Cypriot loss. Most of the Turkish Cypriots believe both sides will gain from the status quo (but less so than they will gain from settlement), but some of them see the continuation as favouring the South more than the North. Again these latter are likely to see the South as preferable because of their particular tourist sector, for example because of the North's lower level of development of tourist services.

Why, then, do only a small minority of the Greek Cypriots, but a large majority of the Turkish Cypriots, see the status quo leading to a win-win? The gap - both in the standard of facilities and

Table III Level of optimism about a settlement within ten years

\begin{tabular}{lcccr} 
& \multicolumn{2}{c}{ Greek Cypriot } & \multicolumn{2}{c}{ Turkish Cypriots } \\
Level of optimism & Frequency & $\%$ & Frequency & $\%$ \\
\hline None at all & 27 & 29.3 & 43 & 61.4 \\
Low level & 18 & 19.6 & 18 & 25.7 \\
Moderate & 19 & 20.7 & 4 & 5.7 \\
High & 14 & 15.2 & 5 & 7.1 \\
Extremely high & 12 & 13.0 & 0 & 0 \\
n/a & 2 & 2.2 & 72 & 100 \\
Total & 92 & 100 & & \\
& & & &
\end{tabular}


in costs - was already beginning to close. The data reflect a diminution in the North's cost advantage and a diminution in the South's infrastructural advantage. Both sides see this and it influences their views about the impact of a continuation of the status quo. Settlement has the effect of offsetting the negatives, and large majorities on both sides see win-win as the result of a settlement for the island's tourism industry in general.

In relation to an understanding of the industry itself, and its structure in terms of the origins of tourists, their perceptions of the future are remarkably similar. Table IV shows that there is a very similar ranking in terms of what tourism professionals North and South see as the important future sources of an increase in tourists to the island of Cyprus in the event of a settlement. Again, as with Tables I and II, the Turkish Cypriots are more optimistic, but apart from the omission of Israel as a source of increase in tourist numbers, the countries mentioned and how important they are perceived to be North and South are similar.

\section{Leading players in tourism in Cyprus}

Of the ten leaders of the tourism industry in the North, many were at the time of the interviews presidents of their associations (of restaurants, hotels, travel agencies, airlines, etc.). They all supported an overall settlement but some expressed the view - supporting our interpretation of the findings in Table III - that "Greek Cypriots are not ready to share power and the market with Turkish Cypriots" (Mehmet et al., 2008, p. 8). Their argument goes further, however, in that they consider both political power and market power. In relation to the latter, many expressed the view that tourism companies in the North operate more efficiently and have lower costs than those in the South. This, they believe, is another reason for reluctance among Greek Cypriots to support a settlement.

The views of Turkish Cypriot tourism industry leaders are in some ways confirmed by those of the Greek Cypriot tourism industry leaders. The General Secretary of the Association of Restaurant Owners in the south, for example, expressed the view that the relative opening up of crossing points between the two sides had resulted in a decline in business for restaurants in the South as people went North; the number of Turkish Cypriot visitors to the South was insufficient to offset this. Other leaders, for example of the hotel associations and the car-rental associations, seem to agree that with the argument that there is unfair competition from the North. They all support an overall settlement, but with many caveats in relation to the details. There does indeed seem to be more hesitation about a settlement among leaders of tourism in the South than in the North.

\section{Conclusion}

The recent revival of negotiations between the elected leaders of Cyprus, North and South, augurs well for the tourism industry. The survey data, and interviews with tourism professionals and representatives, all show overall that there is an expectation on both sides of a win-win for

\section{Table IV Increase in tourism flows from countries given a solution}

\begin{tabular}{lcc} 
& $\begin{array}{c}\text { Greek Cypriots } \\
\%^{a}\end{array}$ & $\begin{array}{c}\text { Turkish Cypriots } \\
\%^{a}\end{array}$ \\
\hline UK & 88.0 & 100.0 \\
Germany & 85.9 & 100.0 \\
Turkey & 75.0 & 95.7 \\
Russia & 73.9 & 100.0 \\
Scandinavia & 69.6 & 98.6 \\
Israel & 69.6 & 0 \\
Arab states & 68.5 & 100.0 \\
Greece & 60.9 & 94.3 \\
Others & 5.4 & 41.4 \\
& & \\
Note: ${ }^{a}$ This is the percent of respondents expecting an increase in tourists from that country \\
Source: Mehmet et al. (2008)
\end{tabular}


tourism in the event of a settlement acceptable to both sides. This expectation is likely to be realised in the event of a settlement. As discussed above, there are differences between the tourist sectors North and South. These differences may in part explain the different attitudes of tourism professionals North and South. However, the differences are also likely to enhance the attractiveness of Cyprus as a tourist destination in the event of a settlement. Yorucu and Mehmet (2011) go further, focussing on specific countries likely to remain among the important origins of tourists to Cyprus, namely, Turkey, Greece and the UK. They conclude that Turkish and Greek tourists have income elastic demand for Cyprus as a tourist destination. Recent economic problems in Greece will therefore reduce Greek tourist response to a settlement in Cyprus but Turkey will become a more important origin for tourism North and South. UK tourists, being more price sensitive, will become less important for tourism in the North, Yorucu and Mehmet (2011) suggest. As a policy recommendation they suggest for the North, but this could be echoed for some tourism providers in the South as well, a focus on more high-income, special interest tourism products, reducing the dependence on low-price, mass market tourism products.

This type of focus on the differences between the North and South and the implications for tourism, supports our interpretation above of the results of the survey of tourism professionals. A settlement of the Cyprus problem, or even a degree of integration of the tourist industries of the two sides, is likely to increase both competition and cooperation between North and South. This will result in an improvement both of the tourism infrastructure to facilitate all-island tourism, and keep prices at internationally competitive levels. If so, this does indeed signal a win-win result of a settlement for tourism North and South.

What is the likelihood of a settlement of the Cyprus problem? More scholarly attention has been paid to this issue than can even be superficially addressed in this paper. Even on so specific an issue as the likely impact on a settlement of the discovery of off-shore natural gas, a recent book (Ker-Lindsay, 2015) contains a variety of views (see Faustmann, 2015; Gürel and Tzimitras, 2015). From the results of our research, the reservations seem to be primarily among Greek Cypriots; this was reflected in the response to the 2004 referendum on the Annan Plan. Some economic explanations for this have been offered above. However, an immediate political factor was that the Greek Cypriot president at the time was Tassos Papadopoulos, and he ultimately opposed the plan - publicly on television - which surely influenced the outcome. The current president, Nicos Anastasiades, was a prominent supporter of the Annan Plan and in the aftermath went so far as to object to the public media's coverage of the referendum, claiming that it was influential in bringing about the rejection in the South (Kulish, 2013; Taki, 2009). He will clearly put a great deal of effort into coming to some kind of agreement over a settlement with his counterpart in the North, Mustafa Akinci. In Akinci he will find a more than willing partner: "the election of Akinci may be the game-changer so desperately needed to break the deadlock" (Smith, 2015b).

What the research presented here shows is that if the reservations in the South over a settlement, both in terms of the political governance issue, and in terms of the business implications for the tourism sector can be overcome, a more strategically rational future for the sector across the island is likely. It should be emphasized, finally, that among the changes since the survey was conducted, the economic crisis in the South and the discovery of natural gas in the Mediterranean in Cypriot waters may well have made a difference to the responses. As well-known political commentator Jonathan Steele has put it, "with recession and the discovery of gas reserves off the Cyprus coast, deadlock with the north is becoming far less convenient" (Steele, 2013). There is reason for the first time in years to be optimistic about the future of tourism in Cyprus, and of Cyprus in general.

\section{References}

Abadie, A. and Gardeazabal, J. (2003), "The economic costs of conflict: a case study of the Basque country", American Economic Review, Vol. 93 No. 1, pp. 113-32.

Altinay, L. (2000), "Possible impacts of a federal solution to the Cyprus problem on the tourism industry of North Cyprus", International Journal of Hospitality Management, Vol. 19 No. 3, pp. 295-309.

Altinay, L., Altinay, M. and Bicak, H.A. (2002), "Political scenarios: the future of the North Cyprus tourism industry", International Journal of Contemporary Hospitality Management, Vol. 14 No. 4, pp. 176-82. 
Altinay, M. and Hussain, K. (2005), "Sustainable tourism development: a case study of North Cyprus", International Journal of Contemporary Hospitality Management, Vol. 17 No. 3, pp. 272-80.

Anderson, J. and O'Dowd, L. (1999), “Contested borders: globalization and ethno-national conflict in Ireland”, Regional Studies, Vol. 33 No. 7, pp. 681-96.

Anson, C. (1999), "Planning for peace: the role of tourism in the aftermath of violence", Journal of Travel Research, Vol. 38 No. 1, pp. 57-61.

Araña, J.E. and León, C.J. (2008), "The ımpact of terrorism on tourism demand", Annals of Tourism Research, Vol. 35 No. 2, pp. 299-315.

Boyd, S. (1999), "North-south divide: the role of the border in tourism in Northern Ireland", Visions in Leisure and Business, Vol. 17 No. 4, pp. 50-71.

Brin, E. (2006), "Politically-orientated tourism in Jerusalem", Tourist Studies, Vol. 6 No. 3, pp. 215-43.

Chung, M. and Yu, L. (2001), "Tourism as a catalytic force for low-politics activities between politically divided countries: the cases of South/North Korea and Taiwan/China”, New Political Science, Vol. 23 No. 4, pp. 537-45.

Cohen-Hattab, K. (2004), "Zionism, tourism, and the battle for Palestine: tourism as a political-propaganda tool”, Israel Studies, Vol. 9 No. 1, pp. 61-85.

Coshall, J.T. (2003), "The threat of terrorism as an intervention on international travel flows", Journal of Travel Research, Vol. 42 No. 1, pp. 4-12.

Dwyer, L., Edwards, D., Mistilis, N., Roman, C. and Scott, N. (2009), "Destination and enterprise management for a tourism future", Tourism Management, Vol. 30 No. 1, pp. 63-74.

Etxebarria, G. and Gomez Uranga, M. (2002), "The impact of conflict on a country's economy: an obligatory response to Beatriz Plaza", European Planning Studies, Vol. 10 No. 3, pp. 391-6.

Faustmann, H. (2015), "Hydrocarbons can fuel a settlement”, in Ker-Lindsay, J. (Ed.), Resolving Cyprus, IB Tauris, London and New York, NY, pp. 74-82.

Flynn, M.K., King, T., Braddon, D. and Dadomo, C. (2012), "Reconciliation and peace economics in Cyprus. Summary of findings (February 2012)", Report to the European Commission (EuropeAid Cypriot Civil Society in Action II Programme), project report, University of the West of England, available at: http://eprints.uwe.ac. uk/17538/

Gelbman, A. (2008), "Border tourism in Israel: conflict, peace, fear and hope", Tourism Geographies, Vol. 10 No. 2, pp. 193-213.

Gelbman, A. and Timothy, D.J. (2011), "Border complexity, tourism and international exclaves: a case study", Annals of Tourism Research, Vol. 38 No. 1, pp. 110-31.

Gürel, A. and Tzimitras, H. (2015), "Gas can become the new lost opportunity", in Ker-Lindsay, J. (Ed.), Resolving Cyprus, IB Tauris, London and New York, NY, pp. 83-92.

Hadjipavlou, M. (2007), "Multiple stories: the 'crossings' as part of citizens' reconciliation efforts in Cyprus?", Innovation, Vol. 20 No. 1, pp. 53-73.

Hall, C.M. and O'Sullivan, V. (1996), "Tourism, political instability and violence”, in Pizam, A. and Mansfeld, Y. (Eds), Tourism, Crime and International Security Issues, Wiley, New York, NY, pp. 105-21.

loannides, D. and Apostolopoulos, Y. (1999), "Political instability, war, and tourism in Cyprus: effects, management, and prospects for recovery”, Journal of Travel Research, Vol. 38 No. 1, pp. 51-5.

Jacobson, D., Musyck, B., Orphanides, S. and Webster, C. (2010), "The opening of the Ledra Crossing in Nicosia: social and economic consequences”, in Butler, R. and Suntikul, W. (Eds), Tourism and Political Change, Goodfellow Publishers, Oxford, pp. 199-207.

Ker-Lindsay, J. (Ed.) (2015), Resolving Cyprus: New Approaches to Conflict Resolution, I.B. Taurus, London.

Kulish, N. (2013), "Conservative is elected president in Cyprus", New York Times, February 24, available at: www.nytimes.com/2013/02/25/world/europe/conservative-candidate-elected-president-incyprus.html?_r=0 (accessed May 19, 2015).

Law, R. (2006), "The perceived impact of risks on travel decisions", International Journal of Tourism Research, Vol. 8 No. 4, pp. 289-300. 
Leigh, J., Webster, C. and Ivanov, S. (Eds) (2013), Future Tourism Political, Social and Economic Challenges, Routledge, London.

Leslie, D. (1999), "Terrorism and tourism: the Northern Ireland situation - a look behind the veil of certainty", Journal of Travel Research, Vol. 38 No. 1, pp. 37-40.

Lisle, D. (2007), “Encounters with partition: tourism and reconciliation in Cyprus”, in Purbrick, L., Aulich, J. and Dawson, G. (Eds), Contested Spaces: Sites, Representations and Histories of Conflict, Palgrave, Basingstoke, pp. 94-146.

McDowell, S. (2008), "Selling conflict heritage through tourism in peacetime Northern Ireland: transforming conflict or exacerbating differences?", International Journal of Heritage Studies, Vol. 14 No. 5 , pp. 405-21.

Mansfeld, Y. (1996), "Wars, tourism and the 'Middle East' factor", in Pizam, A. and Mansfeld, Y. (Eds), Tourism, Crime and International Security Issues, Wiley, New York, NY, pp. 265-78.

Mehmet, O., Jacobson, D., Yorucu, V., Orphanides, S., Michaelides, G., Katircioglu, S., Webster, C., Musyck, B., Violaris, J. and Tahiroglu, M. (2008), "The future of the tourism industry in Cyprus: divided or reunited?". Monograph, The Management Centre of the Mediterranean, Nicosia, March.

Moufakkir, O. and Kelly, I. (Eds) (2010), Tourism, Progress and Peace, CABI, Wallingford, CT.

Musyck, B., Jacobson., D., Mehmet, O., Orphanides, S. and Webster, C. (2010), "Divided or reunited? Prospects for the Cyprus tourism industry", in Moufakkir, O. and Kelly, I. (Eds), Tourism, Progress and Peace, CABI, Wallingford, CT, pp. 212-28.

Neumayer, E. (2004), "The impact of political violence on tourism: dynamic cross-national estimation", Journal of Conflict Resolution, Vol. 48 No. 2, pp. 259-81.

Noë, W. and Watson, M. (2005), "Convergence and reunification in Cyprus: scope for a virtuous circle", ECFIN Country Focus, Vol. 2 No. 3, pp. 1-7, available at: http://ec.europa.eu/economy_finance/publications/ publication1469_en.pdf

Plaza, B. (2002), "A note on panorama of the Basque country and its competence for self-government: terrorism and the Guggenheim Museum Bilbao effect", European Planning Studies, Vol. 10 No. 3, pp. 383-9.

Psillides, C. (2015), “Akinci: practical steps towards a solution”, Cyprus Mail, April 20, available at: http:// cyprus-mail.com/2015/04/20/akinci-practical-steps-towards-a-solution/ (accessed May 15, 2015).

Republic of Cyprus (1961), Census of Population and Agriculture, 1960: Volume I: Population by Location, Race, and Sex, Department of Statistics, Nicosia.

Sachs, S. (2004), “Greek Cypriots reject a UN peace plan”, New York Times, April 25, available at: www. nytimes.com/2004/04/25/world/greek-cypriots-reject-a-un-peace-plan.html (accessed May 20, 2015).

Scott, J. (2012), "Tourism, civil society and peace in Cyprus", Annals of Tourism Research, Vol. 39 No. 4, pp. 2114-32.

Seongseop Kim, S. and Prideaux, B. (2006), "An investigation of the relationship between South Korean domestic public opinion, tourism development in North Korea and a role for tourism in promoting peace on the Korean peninsula", Tourism Management, Vol. 27 No. 1, pp. 124-37.

Sharpley, R. (2001), "Tourism in Cyprus: challenges and opportunities", Tourism Geographies, Vol. 3 No. 1, pp. 64-86.

Smith, H. (2015b), "Divided Cyprus begins to build bridges", The Guardian, June 1, available at: www. theguardian.com/world/2015/may/31/mustafa-ankinci-advocates-focus-future-for-splintered-cyprus (accessed June 4, 2015).

Sönmez, S. and Apostolopoulos, Y. (2000), "Conflict resolution through tourism cooperation? The case of the partitioned island-state of Cyprus", Journal of Travel \& Tourism Marketing, Vol. 9 No. 3, pp. 35-48.

Steele, J. (2013), "Why Greek Cypriots need to get serious about peace”, The Guardian, June 3, available at: www.theguardian.com/commentisfree/2013/jun/03/greek-cypriots-get-serious-about-peace (accessed June 5, 2015).

Taki, Y. (2009), "The plan, public discourse and the role of the mass media in getting to 'no'”, in Varnava, A. and Faustmann, H. (Eds), Reunifying Cyprus: The Annan Plan and Beyond, I.B. Tauris, London, pp. 180-93. 
Tourism \& Transport Consult International (2004), "Study for the determination of the impact on tourism from a potential settlement of the Cyprus issue on the basis of the Annan Plan - final report", Cyprus Tourism Organisation, Dublin.

Vural, Y. and Peristianis, N. (2008), "Beyond ethno-nationalism: emerging trends in Cypriot politics after the Annan Plan”, Nations and Nationalism, Vol. 14 No. 1, pp. 39-60.

Webster, C. and Ivanov, S. (2014), "Tourism as a force for political stability", in Wohlmuther, C. and Wintersteiner, W. (Eds), The International Handbook on "Tourism and Peace", Drava Verlag, Klagenfurt/ Celovec, pp. 167-80.

Webster, C. and Timothy, D.J. (2006), "Travelling to the 'other side': the occupied zone and Greek Cypriot views of crossing the Green Line", Tourism Geographies, Vol. 8 No. 2, pp. 162-81.

Webster, C., Musyck, B., Orphanides, S. and Jacobson, D. (2009), "Working on the other side. co-operative tour organizers and uncooperative hoteliers: evidence from Greek Cypriot tourism professionals", European Planning Studies, Vol. 17, pp. 1485-508.

Wohlmuther, C. and Wintersteiner, W. (2014), The International Handbook on "Tourism and Peace", Drava Verlag, Klagenfurt/Celovec.

Yeoman, I. (2008), Tomorrow's Tourist: Scenarios \& Trends, Elsevier, London and New York, NY.

Yeoman, I. (2012), 2050 - Tomorrow's Tourism, Channel View Publications, London.

Yeoman, I. and Lederer, P. (2005), "Scottish tourism: visions and scenarios", Journal of Vacation Marketing, Vol. 11 No. 1, pp. 67-83.

Yorucu, V. and Mehmet, O. (2011), "The bounds-test approach for co-integration between international tourist arrivals, per capita income and cost of living: the case of all Cyprus", Applied Economics Letters, Vol. 18 No. 14, pp. 1327-31.

Zuelow, E.G.E. (2006), "Ingredients for cooperation: Irish tourism in North-South relations, 1924-1998", New Hibernia Review, Vol. 10 No. 1, pp. 17-39.

\section{Further reading}

Smith, H. (2015a), "Cyprus peace talks raise hopes of an end to a conflict that has haunted Europe", The Guardian, May 14, available at: www.theguardian.com/world/2015/may/14/cyprus-peace-talks-raisehopes-end-conflict-haunted-europe (accessed May 24, 2015).

\section{Corresponding author}

Craig Webster can be contacted at: cwebster3@bsu.edu

For instructions on how to order reprints of this article, please visit our website: 